http://journal.uinsgd.ac.id/index.php/biodjati

\title{
STUDIES ON FERN OF LESSER SUNDA ISLANDS I: CHECKLIST OF THE GENUS Adiantum (PTERIDACEAE)
}

\author{
Wenni Setyo Lestari ${ }^{1 *}$, Bayu Adjie $^{2}$
}

Received : November 07, 2019

Accepted : April 28, 2020

DOI: 10.15575/biodjati.v5i1.6365

${ }^{1}$ Eka Karya Bali Botanic Garden, Research Center for Plant Conservation and Botanic Garden - Indonesian Institute of Sciences, Candikuning, Baturiti, Tabanan, Bali 82191

${ }^{2}$ Purwodadi Botanic Garden - Indonesian Institute of Sciences,

Jl. Raya Surabaya - Malang Km. 65,

Purwodadi, Pasuruan, Jawa Timur 67163

\begin{abstract}
Adiantum or maidenhair fern is one of the largest genera in Pteridaceae. We survey their species diversity in Lesser Sunda Islands, Indonesia through the living collection and herbarium examination. Seventeen species of Adiantum were recorded. including five species that considered as introduced and naturalized species. One species that grows naturally, Adiantum silvaticum, were previously known as endemic to Australia. However, this study revealed the new distribution of this species on Sumba and Flores.
\end{abstract}

Keywords: Adiantum, maidenhair fern, Lesser Sunda Islands

e-mail:

*1wenn001@lipi.go.id

²bayu.adjie@lipi.go.id

*Corresponding author

\section{Citation}

Lestari, W. S. \& Adjie, B. (2020). Studies on Fern of Lesser Sunda Islands I: Checklist of the Genus Adiantum (Pteridaceae). Jurnal Biodjati, 5(1), 107-114.

\section{INTRODUCTION}

Adiantum is a fern genus of Pteridaceae in the order of Polypodiales (Smith et al., 2006). Known as a maidenhair fern (or suplir in Indonesia), it consists of about 200 species or more (Tagawa \& Iwatsuki, 1985; Zhang et al., 2013). This fern mostly used as an ornamental plant due to its attractive leaf appearance. Some species were reported used as a vegetable or ethnomedicinally due to its phytochemicals compound and biological activities, for example, Adiantum capillus-veneris, A. flabellulatum, A. pedatum and A. venustum (Afriastini, 2003; Brahmachari et al., 2003).

The botanical name Adiantum (unwet- ted) refers to how water-drops run off the surface of the pinnae without wetting them (Holttum, 1954). This genus can be recognized by the polished black leaf stalks and specialized reflexed margins of the lamina (false indusia) that covered the sori (Korpelainen et al., 2005). Adiantum can be found in many parts of the world, mainly in the tropical and subtropical regions (Hoshizaki \& Moran, 2002; Korpelainen et al., 2005). Based on herbarium deposited in Herbarium Bogoriense (BO), the genus is found widely distributed on the island of Indonesia including southeastern archipelago known as Lesser Sunda Islands (LSI). The main Lesser Sunda Islands found from west to east are in Bali, Lombok, Sum- 


\section{JURNAL BIDDJATI}

http://journal.uinsgd.ac.id/index.php/biodjati

bawa, Flores, Sumba, Timor, Alor archipelago, Barat Daya Islands and Tanimbar Islands (Figure 1).

The only study on ferns in this region conducted by Posthumus (Posthumus, 1944). He reported 11 species of Adiantum from the
Lesser Sunda Islands. Botanical exploration conducted by Bali Botanic Garden that did a notable collection for Adiantum was recorded to start in 1984. This study purposed to review diversity and distribution on the genus Adiantum after more than seven decades.

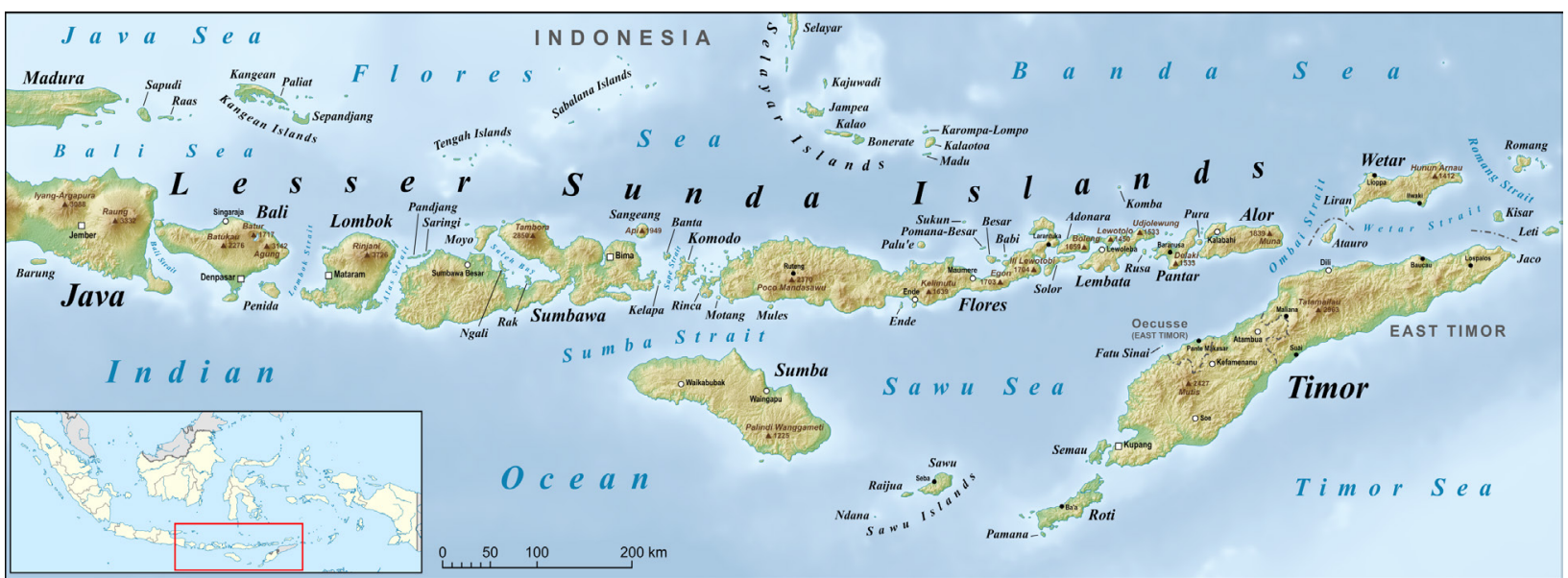

Figure 1. Lesser Sunda Islands, Indonesia (Source: Wikipedia, n.d.)

\section{MATERIALS AND METHODS}

Materials examined were Bali Botanic Garden's living collection originated from Lesser Sunda Islands (Bali, Lombok, Sumbawa, Timor, Sumba, Flores) that collected in 1984 up to 2013, compared with herbarium specimen stored at Herbarium Bogoriense (BO) and Herbarium Bali Botanic Garden (THBB). Identification of the specimens was referred to some literature (Holttum, 1968; Knapp, 2011; Matsumoto et al., 2008; Posthumus, 1944; Tagawa \& Iwatsuki, 1985; Zhang et al., 2013). Any distribution and their habitat were presented based on Posthumus (1944), Zhang et al. (2013) and herbarium records.

\section{RESULTS AND DISCUSSION}

Posthumus (1944) reported 11 species of Adiantum found in LSI (Bali, Lombok, Sumbawa, Timor, Sumba, Flores, Wetar and Alor Island) (Table 1.). An examination from the Bali Botanic Garden living collection of Adiantum also found 11 species originated from Lesser Sunda Islands (Bali, Lombok, Sumbawa, Timor, Sumba, Flores). Unfortunately, there is no collection record from Wetar and Alor.

No endemics found in the Lesser Sunda Islands. Most of the species have a wide distributional range, especially in Asia. Five species of Adiantum were recognized as the common species and also mentioned in the previous study by Posthumus (1944), i. e. $A d$ iantum caudatum, A. diaphanum, A. edgeworthii, A. hispidulum and A. philippense. Those species quite easy to find and abundant, however, A. edgeworthii only collected from the high altitude of Timor. 
Jurnal Biodjati 5(1):107-114, May 2020

\section{JURNAL BIDDJATI}

http://journal.uinsgd.ac.id/index.php/biodjati

Table 1. List of Adiantum Species from Lesser Sunda Islands

\begin{tabular}{|c|c|c|c|}
\hline Species & Locality & $\begin{array}{c}\text { Posthumus } \\
\text { (1944) }\end{array}$ & $\begin{array}{l}\text { Bali Botanic } \\
\text { Garden Living } \\
\text { Collection }\end{array}$ \\
\hline Adiantum sp. $^{2}$ & Bali & - & + \\
\hline \multirow[t]{3}{*}{ A. capillus-veneris L. ${ }^{1}$} & Lombok & + & - \\
\hline & Timor & + & - \\
\hline & Sumba & + & - \\
\hline \multirow[t]{7}{*}{ A. caudatum $\mathrm{L} .{ }^{1}$} & Bali & + & + \\
\hline & Lombok & + & - \\
\hline & Sumbawa & + & - \\
\hline & Flores & + & - \\
\hline & Wetar & + & - \\
\hline & Sumba & + & - \\
\hline & Timor & + & - \\
\hline \multirow[t]{2}{*}{ A. concinnum Humb. \& Bonpl. ex Willd. ${ }^{2}$} & Bali & - & + \\
\hline & Lombok & - & + \\
\hline A. cuneatum Langsd. \& Fisch. ${ }^{1}$ & Alor & + & - \\
\hline \multirow[t]{4}{*}{ A. diaphanum Blume $^{1}$} & Bali & + & + \\
\hline & Lombok & + & - \\
\hline & Flores & + & - \\
\hline & Timor & + & - \\
\hline A. edgeworthii Hook. ${ }^{1}$ & Timor & + & + \\
\hline \multirow[t]{3}{*}{ A. flabellulatum L. ${ }^{1}$} & Bali & + & - \\
\hline & Sumbawa & + & - \\
\hline & Flores & + & - \\
\hline \multirow[t]{6}{*}{ A. hispidulum $\mathrm{Sw}^{1}$} & Sumba & + & + \\
\hline & Lombok & + & + \\
\hline & Bali & + & + \\
\hline & Timor & + & + \\
\hline & Flores & + & - \\
\hline & Alor & + & - \\
\hline A. peruvianum Klotzsch ${ }^{3}$ & Bali & - & + \\
\hline \multirow[t]{7}{*}{ A. philippense L. ${ }^{1}$} & Bali & + & + \\
\hline & Lombok & + & + \\
\hline & Wetar & + & - \\
\hline & Sumbawa & + & - \\
\hline & Sumba & + & - \\
\hline & Timor & + & - \\
\hline & Alor & + & - \\
\hline \multirow[t]{2}{*}{ A. pulchellum Blume ${ }^{1}$} & Sumbawa & + & - \\
\hline & Flores & + & - \\
\hline A. raddianum C. Presl. ${ }^{2}$ & Bali & - & + \\
\hline \multirow[t]{3}{*}{ A. mettenii Kuhn. ${ }^{1}$} & Bali & + & - \\
\hline & Flores & + & - \\
\hline & Timor & + & - \\
\hline \multirow[t]{2}{*}{ 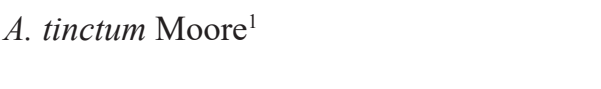 } & Lombok & + & - \\
\hline & Timor & + & - \\
\hline A. trapeziforme L. ${ }^{2}$ & Sumbawa & - & + \\
\hline \multirow[t]{2}{*}{ A. silvaticum Tindale } & Sumba & - & + \\
\hline & Flores & - & + \\
\hline
\end{tabular}

${ }^{1}$ Native species; ${ }^{2}$ Introduced and naturalized species; ${ }^{3}$ Introduced and cultivated species 


\section{JURNAL BIDDJATI}

http://journal.uinsgd.ac.id/index.php/biodjati

Adiantum caudatum Linnaeus, Mant. P1. 308. 1771.

\section{Specimen Examined}

In rocks crevices on lowland area at Tenganan Village, Manggis District, Karangasem Regency, Bali WN132 and WN136; terrestrial on slope and roadside of Dawan Village, Dawan District, Klungkung Regency, Bali WN140; on limestone rock at Mount Prapat Agung, North West Bali KK + SS 38; Mount Kelatakan, Bali R. Maier Sarip 160; Mount Ndeki, West Flores Kosterman \& Wirawan 156; Soemba Iboet 304; Soembawa Rensch 835.

Habitat

Occurs in full sun habitat on exposed sandstone.

\section{General Distribution}

Bhutan, Cambodia, China, India, Indonesia, Laos, Malaysia, Myanmar, Nepal, Philippines, Thailand, Vietnam; throughout Old World Tropics (Zhang et al., 2013).

Adiantum diaphanum Blume, Enum. Pl. Javae 2: 215. 1828.

\section{Specimen Examined}

Bali Botanic Garden (1250 m asl), Baturiti District, Tabanan Regency, Bali WN112; Lake Buyan (1215 m asl), Sukasada District, Buleleng Regency, Bali WN121; Munduk Pengubengan (1060 m asl), Karangasem Regency, Bali BA754a; the west slope of Mount Inie Lika Posthumus 3130; along a trail between Wolu (sea level) and Batu (Mount) Kokan, southern slope of Manusela Ridge, District Tehoru, Manusela National Park, C. Seram M. Kato, K. Ueda, M. Okamoto, H. Akiyama, B. Sunarno, U. W. Mahjar 6546; Halmahera, Moluccas Idjan/Mochtar 171; Bali Posthumus 3667.

\section{Habitat}

Occurs in full sun habitat on an exposed stone fence, on the rocky slope, road, or riverside.

\section{General Distribution}

China, Indonesia, Malaysia, Vietnam; Australia, Pacific Islands (New Zealand, Polynesia) (Zhang et al., 2013).

Adiantum edgeworthii Hooker, Sp. Fil. 2: 14. 1851.

\section{Specimen Examined}

Mount Mutis Natural Reserve (1600 m asl), Fatumnasi Village, Fatumnasi District, Timor Tengah Selatan Regency, Timor BA742; Timor S. Bloembergen 3534 (Adiantum caudatum var. edgeworthii).

\section{Habitat}

Occurs in full sun habitat on roadside.

\section{General Distribution}

Bhutan, China, India, Indonesia, Japan, Malaysia, Myanmar, Nepal, Philippines, Thailand, Vietnam (Zhang et al., 2013).

Adiantum hispidulum Swartz in Schrader, J. Bot. 1800: 82. 1802.

\section{Specimen Examined}

Giriloka Sub Village (1200 m asl), Pancasari Village, Sukasada District, Buleleng Regency, Bali WN120; Laiwangi Wanggameti National Park (1300 m asl), Sumba Timur Regency, Sumba $B A 809$; near spring, Mount Mutis Natural Reserve (1665 m asl), Fatumnasi Village, Fatumnasi District, Timor Tengah Selatan Regency, Timor BA706; Lombok Timor Regency, Lombok WT797; farm area of Junrejo District, Batu City, Java WN144; Gunong Kumapodahu, District Kolaka, Southeast Sulawesi J. Wen 10243 and Abdul Kartonegoro.

\section{Habitat}

Occurs on exposed slope or roadside.

\section{General Distribution}

China, India, Indonesia, Malaysia, Philippines; tropical and subtropical regions : Africa, Asia, Pacific Islands (Zhang et al., 2013). 


\section{JURNAL BIDDJATI}

http://journal.uinsgd.ac.id/index.php/biodjati

Adiantum philippense Linnaeus, Sp. Pl. 2: 1094. 1753.

\section{Specimen Examined}

Padangbulia Village, Buleleng Regency, Bali WN128; Suranadi Village, Lombok Barat Regency, Lombok WN142; Mount Rinjani National Park (674 m asl), Senaru Village, Bayan District, Lombok Utara Regency, Lombok SH1130; Malang City, Java WN153; based of Gunong Pondunaa in Mount Watu Wila, District Kolaka, Southeast Sulawesi $J$. Wen 10206 and Abdulkartonegoro.

\section{Habitat}

Occurs on exposed rocks crevices or roadside.

\section{General Distribution}

Bhutan, China, India, Indonesia, Kashmir, Malaysia, Myanmar, Nepal, Philippines, Thailand, Vietnam; tropics and subtropics of Africa, Oceania (Zhang et al., 2013).

Another four Adiantum species, i. e. Adiantum concinnum Humb. \& Bonpl. ex Willd., A. peruvianum Klotzsch, A. raddianum C. Presl. and A. trapeziforme L., did not mention by Posthumus in his publication. It is probably because those species were Neotropics origin and considered as introduced species that become naturalized or cultivated recently. Adiantum concinnum was found in Bali and Lombok. Specimen from Bali grows on rocky habitat and the size is smaller than Lombok's specimen. This species can be recognized by the innermost segments of the pinnae overlapping the rachis. Adiantum concinnum is reported native to tropical America (Hoshizaki \& Moran, 2002). Adiantum peruvianum was found in Bali, cultivated at a home yard as an ornamental plant. This species is native to Ecuador, Peru and Bolivia (Hoshizaki \& Moran, 2002).
Adiantum raddianum from Bali grows on the same habitat as $A$. concinnum. This species is native to the American tropics and becomes the most commonly cultivated maidenhair in the United States with numerous, poorly defined and confusing cultivars (Hoshizaki \& Moran, 2002). Adiantum trapeziforme is a native species in America and the West Indies (Hoshizaki \& Moran, 2002). Bali Botanic Garden living collection originated from Sumbawa and grows on a rocky habitat, at the open area near the stream, far from civilization. Its originality in LSI still needs to be confirmed.

Another unidentified specimen, Adiantum sp., also considered as non-native species. This specimen found in Bali on rocky habitat together with $A$. concinnum and $A$. raddianum. The morphology of this species is similar to an Adiantum species found in Hawaii with less information.

Some species found by Posthumus (1944) in the Lesser Sunda Islands have not been collected by Bali Botanic Gardens yet, i. e. A. capillus-veneris L., A. cuneatum Langsd. \& Fisch., A. flabellulatum L., A. pulchellum Blume, A. mettenii Kuhn. and A. tinctum Moore. Adiantum cuneatum and A. tinctum were recorded as a synonym of $A$. raddianum. Based on herbarium examination on BO, $A$. cuneatum and $A$. tinctum from the previous records have a bigger leaflet, while $A$. raddianum from Bali Botanic Gardens collection has a smaller leaflet. In this paper, those specimens then threatened as different specimens. Adiantum pulchellum and A. mettenii recorded as the unresolved name.

Adiantum silvaticum Tindale (Figure 2.)

Contr. New South Wales. Natl. Herb. 3: 246 (1963). Type: E. F. Constable (NSW); iso: KYO, TI. 


\section{JURNAL BIDDJATI}

http://journal.uinsgd.ac.id/index.php/biodjati
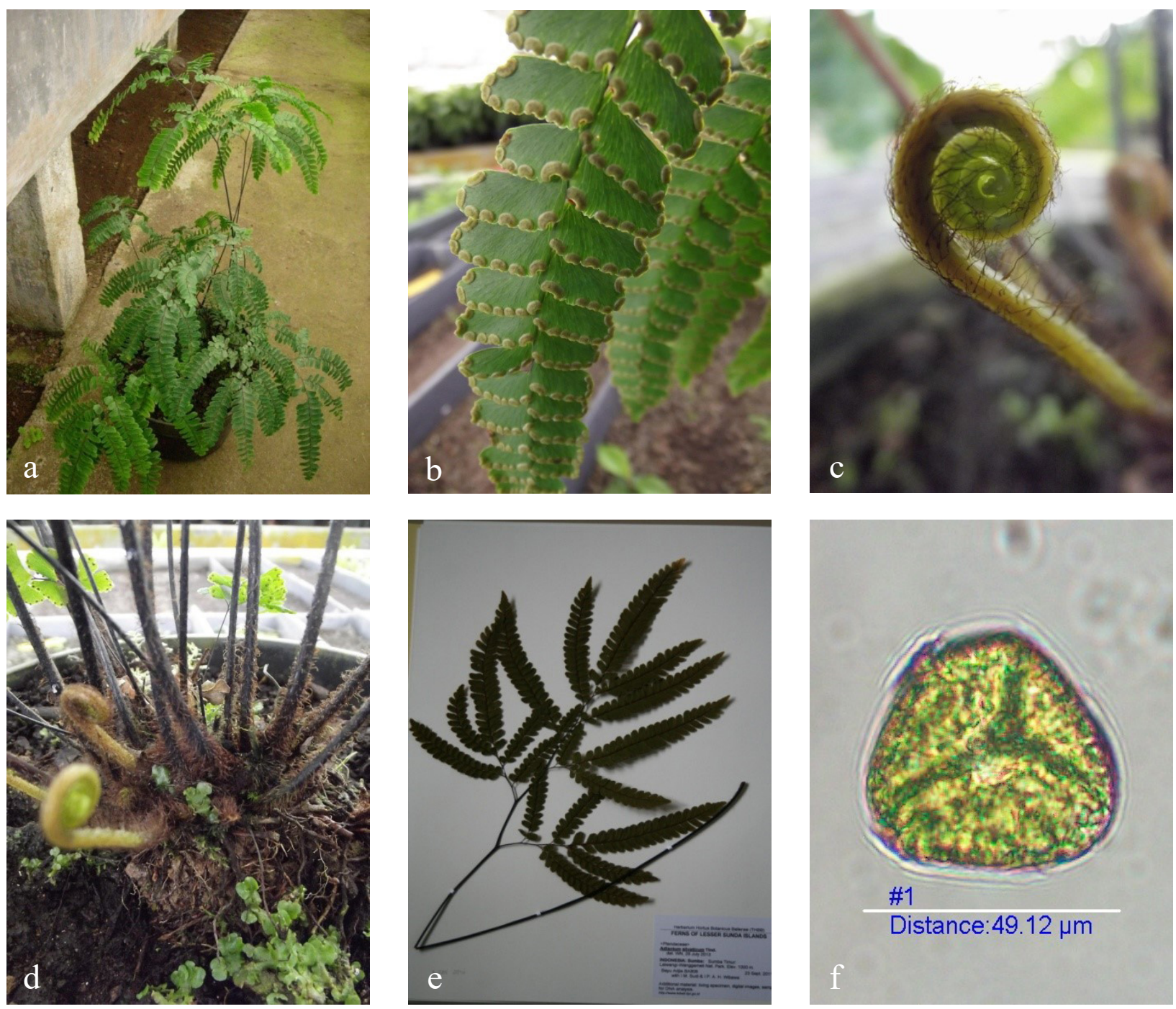

Figure 2. Adiantum silvaticum Tindale from Sumba : habitus (a); sporangia (b); fiddlehead (c); base of fronds (d); herbarium specimen (e); spores, MAG 40 (f)

Rhizome creeping, much-branched, c. 5 mm diam.; scales golden brown, concolorous, with shortly ciliate margins and setose apices. Fronds scattered, to $80 \mathrm{~cm}$ long. Stipe to 65 cm long, glossy, sometimes scabrous proximally. Lamina 2- or 3-pinnate at the base, triangular to pentagonal, 15-30 cm long, 15-30 $\mathrm{cm}$ wide, herbaceous to coriaceous, bright green or bluish-green; rachis glossy and glabrous abaxially, black or with a dark purple hue, densely clothed with antrorse red-brown hairs adaxially (rarely partially or completely glabrous). Higher-order segments hastate or Lestari \& Adjie narrowly to broadly triangular. Primary pinnae all \pm same length and degree of branching. Pinnules symmetric and flabellate, or dimidiate and trapeziform to rectangular with blunt or upcurved apices, glabrous, often glaucescent but never glaucous abaxially; veins arising in part from a basiscopic submarginal vein. Sori 1-10 along the distal margins, commonly 1 per lobe; soral flaps rectangular to subreniform, glabrous. Spores yellow; perine finely granulose, loosely adhering to exine; largest diam. (31-) c. $42(-52) \mu \mathrm{m}$. 


\section{JURNAL BIDDJATI}

http://journal.uinsgd.ac.id/index.php/biodjati

Adiantum silvaticum Tindale was known as endemic to eastern Queensland and New South Wales south to about U1ladulla, Australia (Bostock, 1998). This specimen first described as $A$. affine Willd. var. intermedium, but the name of $A$. affine then known as synonym of $A$. capillus-veneris $\mathrm{L}$. The Australia's specimen latter given name as $A$. cunninghamii Hook., but since the differences on spore size and the colour of the rachis scales, the Australia's specimen then given name as $A$. silvaticum Tindale (Parris \& Croxall, 1974). In Australia, this species grows terrestrial in the rainforest and tall hardwood forests, often showing a preference for poorer soils; occasionally lithophytic on sandstone cliffs along creeks or rivers; 20 to over $1100 \mathrm{~m}$ asl. Its lowland occurrences, particularly in southern Queensland, are usually in palm-dominated rainforest some distance from the coast (Bostock, 1998).

Field work to Laiwangi-Wanggameti National Park on Sumba and Lake Ranamese on Flores found an Adiantum species that considered to A. silvaticum Tindale (Figure 1). Morphologically, A. silvaticum Tindale is similar to another three Adiantum species endemic to New Zealand, A. cunninghamii Hook., A. fulvum Raoul and A. viridescens Col. (Parris \& Croxall, 1974). The sequence of the trnL-F region from Sumba's specimen (GenBank accession number: LC004395 and LC004396) (Lestari et al., 2014) confirmed that this specimen is closely related to those three Adiantum species. Unfortunately, no DNA record from the Australian specimen in GenBank yet.

\section{Record Voucher from the Lesser Sunda Is- lands localities. INDONESIA. Sumba}

River banks or mountain slope, humus soil, shaded areas at $1010-1300 \mathrm{~m}$ asl, Sum- ba Timur Regency, Laiwangi-Wanggameti National Park, Sumba Island, Nusa Tenggara Timur.

Living Collection: Three specimens, previously identified as Adiantum sp. (Collector: Drapemmu.103, Accession number: E199610136). Four specimens; previously identified as A. polyphyllum Willd. (Collector: PEN539, Accession Number: E200610284). Two specimens; previously identified as A.hispidulum Sw. (Collector: BA808, Accession number: E20111147) and Adiantum sp. (Collector: BA817, Accession: E20111156).

Herbarium Specimen: THBB.

\section{Flores}

1115 m asl, Lake Ranamese, Taman Wisata Alam Ruteng, Manggarai District, Flores Island, Nusa Tenggara Timur.

Living Collection: one specimen (Collector: SH 1925, Accession: E2014120073). Herbarium Specimen: THBB.

Based on living collection and herbarium examination, seventeen species of Adiantum recorded from Lesser Sunda Islands of Indonesia. One of the specimens, A. silvaticum, is a new record for Lesser Sunda Islands of Indonesia. Adiantum was distributed almost on every island of Lesser Sunda and cosmopolite. Since the islands have a very unique size and ecological features, we encourage to survey more islands and genera in the future.

\section{ACKNOWLEDGEMENTS}

We would like to thank the Head of the Botany Division-Research Center for Biology-Indonesian Institute of Sciences for the permission of the herbarium examination and also Bali Botanic Garden's Plant Registration Unit for the data of the Adiantum collection. 


\section{JURNAL BIDDJATI}

http://journal.uinsgd.ac.id/index.php/biodjati

\section{REFERENCES}

Afriastini, J. J. (2003). Adiantum L. In W. P. de Winter \& V. B. Amoroso (Eds.), Plant Resources of South-East Asia No. 15(2) Cryptogams: Ferns and Fern Allies. PROSEA.

Bostock, P. D. (1998). Adiantum. In A. E. Orchard \& M. P. McCarthy (Eds.). Flora of Australia Volume 48: Ferns, Gymnosperms and Allied Groups. CSIRO.

Brahmachari, G., Mondal, S., Chatterjee, D. \& Brahmachari, A. K. (2003). Phytochemicals and Biological Activities of Adiantum Species. Journal of Scientific \& Industrial Research, 62(12), 11191130.

Holttum, R. E. (1954). A Revised Flora of Malaya II: Ferns of Malaya. Singapore: Government Printing Office.

Holttum, R. E. (1968). Flora of Malaya Vol. II: Ferns of Malaya (2nd ed.). Singapore: Government Printing Office.

Hoshizaki, B. J. \& Moran, R. C. (2002). Fern Grower's Manual. USA: Timber Press Inc.

Knapp, R. (2011). Ferns and Fern Allies of Taiwan. Taiwan: KBCC Press \& Yuan-Liou Publishing.

Korpelainen, H., De Britto, J., Doublet, J. \& Pravin, S. (2005). Four Tropical, Closely Related Fern Species Belonging to the Genus Adiantum L. are Genetically Distinct as Revealed by ISSR Fingerprinting. Genetica, 125(2-3), 283-291.

Lestari, W. S., Adjie, B., Jaruwatanaphan, T., Watano, Y. \& Pharmawati, M. (2014). Molecular Phylogeny of Maidenhair Fern Genus Adiantum (Pteridaceae) from Lesser Sunda Islands Indonesia based on rbcL and trnL-F. Reinwardtia, 14(1), 143-156.
Matsumoto, S., Nose, T., Nakamura, T., Sugisaki, Y. \& Yoshikawa, N. (2008). Pteridaceae. In T. Nakamura \& S. Matsumoto (Eds.), The National Museum of Nature and Science Series No. 8: Illustrated Flora of Ferns and Fern-Allies of South Pacific Islands. Japan: Tokai University Press.

Parris, B. S. \& Croxall, J. P. (1974). Adiantum viridescens Colenso in New Zealand. New Zealand Journal of Botany, 12(2), 227-233.

Posthumus, O. (1944). Malayan Fern Studies III: The Ferns of the Lesser Sunda Islands. Annals of the Botanic Gardens, 51(1), 84-88.

Smith, A. R., Pryer, K. M., Schuettpelz, E., Korall, P., Schneider, H. \& Wolf, P. G. (2006). A Classification for Extant Ferns. Taxon, 55(3), 705-731.

Tagawa, M. \& Iwatsuki, K. (1985). Flora of Thailand. Vol. 3, Part 2 (Vittariaceae, Pteridaceae, Aspleniaceae) (T. Smitinand \& K. Larsen (eds.)). Thailand: Royal Forest Department.

Wikipedia. (n.d.). Retrieved from https:// en.wikipedia.org/wiki/Lesser_Sunda Islands\#/media/File:Lesser_Sunda_Islands_en.png.

Zhang, G. M., Liao, W. B., Ding, M. Y., Lin, Y. X., Wu, Z. H., Zhang, X. C., Dong, S. Y., Prado, J., Gilbert, M. G., Yatskievych, G., Ranker, T. A., Hooper, E. A., Alverson, E. R., Metzgar, J. S., Funston, A. M., Masuyama, S. \& Kato, M. (2013). Pteridaceae. In Y. Z. Wu, P. H. Raven, \& D. Y. Hong (Eds.), Flora of China Vol. 2-3 (Pteridophytes). USA: Missouri Botanical Garden Press. 